\title{
Acts of God are not the problem
}

\author{
Human negligence turns hazards into disasters
}

\author{
Seth Sicroff
}

Mountain tourism both increases the risks posed by mountain hazards and also provides the economic opportunity to effectively cope with those hazards. Salient points and recommendations from participants in "Mountain Hazards, Mountain Tourism" e-conference include:

- Although climate change is increasing the likelihood of glacial lake outburst floods (GLOFs), we now have the scientific tools to monitor and quantify such hazards.

- Unfortunately, those tools are not being used on a regular basis. This increases the hazard of media sensationalism, which in turn increases the risk of serious economic damage as well as lost scientific credibility.

- Contrary to published reports, the hazard mitigation project at Tsho Rolpa in Rolwaling was left in an incomplete state and without provision for scientific monitoring; the lake still poses a great risk.

- More attention must be paid to the human component of mountain hazards. Ethnic cleansing programs such as the current disaster in Bhutan cause suffering and economic damage on a scale that beggars most natural events.

- A useful step toward the rational confrontation with all sorts of disasters (not just those that impact mountains) would be the conversion of King Gyanendra's palace into a Disaster Management University.

This paper is a synthesis of an e-conference held on the Mountain Legacy listserv from Nov 7 to Dec 7, 2006. The discussion was originally intended as a precursor to a "face-to-face" event, The Rolwaling Conference: Mountain Hazards, Mountain Tourism, which was canceled due to lack of sufficient funding. The wrap-up is by no means comprehensive; we urge you to read the details in the archived discussion at www.econf.org.

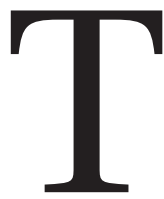

he Rolwaling Conference was to have three interlocking agendas: a general theme (mountain hazards as they relate to mountain tourism), a specific geographic focus on Rolwaling Valley, and a logistical and conceptual roundtable on a proposed interdisciplinary research station to be established in Rolwaling Valley. The latter theme was omitted from the e-conference agenda.

Active participation in the e-conference was limited primarily to important presentations from three experts, plus ancillary discussion and commentary by a few other participants. A keynote presentation, "Fools rush in: A mountain dilemma", was contributed by Prof Jack D Ives, Carleton University, Ottawa, Canada. A second feature presentation was "Glacial hazard assessment and risk management: Lessons from Tsho Rolpa and new perspectives," by Professor John M Reynolds, Managing Director, Reynolds Geo-Sciences, Ltd (RGSL). Dr Janice Sacherer, an anthropologist with the University of Maryland University College Asia (Okinawa) contributed "Tsho Rolpa, GLOFs, and the Sherpas of Rolwaling Valley: A brief anthropological perspective."

\section{Mountain tourism}

Tourism has the potential to alleviate many problems in impoverished mountain areas. First, it offers economic opportunities that are greater and also less destructive than extractive industries (such as logging or hunting) and outmigration. Second, tourism generally entails the expansion of services deemed necessary for recreational comfort. Electricity, medical services, imported foods, warmer clothing, and other perquisites are eventually extended to host communities. In the same way, concern for the safety of tourists (as well as downstream infrastructure) can result in huge expenditures for the mitigation of hazards which would not likely be undertaken merely for the sake of those who live with them on a year-round basis.

The downside of tourism is dependency on a market that can collapse instantaneously and for reasons beyond the control of those involved in the tourism trade. Global and regional political instability, terrorism, and economic recession can all effectively quench people's taste for recreational travel. Real or perceived hazards at the remote destination site can result in a redirection of traffic that may last longer than the threat itself, whether or not the disaster materializes.

\section{Mountain hazards}

What exactly do we mean by "mountain hazards"? Normally we think of threats to human life and property that are posed by natural processes - generally by extreme events, often aggravated (or even caused) by human activity. Floods and mass wasting are the most familiar agents. But if we are thinking in terms of mitigation strategies, we should probably look at the entire range of "bad things" that happen in the mountains. In this context, Ives brings up the ongoing 
Bhutanese "crimes against humanity," which have caused more suffering than nearly any other mountain disaster on record, and also pose a substantial threat of regional armed conflict. Of course, there are more commonplace disasters. For instance, the unavailability of modern medical services is arguably the cause of nearly every single death in remote areas. How do we assign priorities for hazard mitigation when the aggregate cost of ordinary flash floods during the monsoon probably exceeds anything we might attribute to a certifiable disaster such as a glacial lake outburst flood (GLOF)?

On the other hand, there is a danger of paralysis in the headlights of equity. "To do nothing unless the whole picture is addressed," Reynolds observes, "is unrealistic."

\section{Mountain hazard \#1: The media}

Both Ives and Reynolds have addressed the issue of an ill-informed and irresponsible press. In some cases, there is simply a distortion of expert views. Reynolds alludes to misrepresentations even in supposedly reliable publications such as New Scientist. However, as Ives has made clear in Himalayan Dilemma and more recently in Himalayan Perceptions, sensationalism is nurtured by bad science and corrupt politics. The risks include distorted priorities (and therefore unfair and ineffective use of limited resources), loss of scientific credibility, defamation of population sectors wrongly accused of causing or exacerbating the hazard, and failure to recognize and/or act on hazards that are politically less glamorous.

Reynolds cites the example of the 2003 fiasco surrounding Palcacocha, Peru. The crisis began when NASA published a press release based on ASTER satellite imagery that was incorrectly interpreted as showing cracks in a glacier, portending imminent collapse and glacial flood. Losses in the tourism sector have been estimated at \$20 million. Both NASA and New Scientist, which gave the story extensive play, declined to issue retractions or even to remove the false reports from their Web sites.

In Nepal, the 1997 panic over the Tsho Rolpa threat led to a costly disruption of economic activity in Rolwaling Valley, and concomitant mass-wasting of scientific credibility. Nonetheless, another media feeding-frenzy accompanied the publication of the UNEP/ICIMOD Inventory of glaciers for Nepal and Bhutan (Mool et al. 2000). Because the inventory omitted any specific assessment of actual hazards posed by the lakes catalogued, and because it included some lakes that are not hazardous (while excluding some that are), it gives a misleading impression about the extent of the hazards.

Reynolds agrees that media inaccuracy is a problem, but notes that the distortions cut both ways:

Undoubtedly there have been exaggerations for effect in some quarters, for a variety of reasons, and such excesses are to be deplored, but so too are the protestations of the vociferous few who downplay the seriousness of the adverse effects of climate change, however it is caused.

\section{Mountain hazard \#2: Armed conflict}

Ives points out that the greatest devastation to mountain peoples is caused by conflict. The modalities range from conventional warfare (as in Afghanistan and Kashmir) to guerrilla insurrections (as in Nepal) to the "expropriation of land for major infrastructure or for the establishment of national parks; and pervasive discrimination against the poor, the under-privileged, and the politically marginalized." One under-reported and on-going disaster is the oppression of the Lhotsampa by the government of Bhutan, resulting in the displacement of some 100,000 refugees.

Again, Ives accuses the press and the politicians of distorting the truth. Development agencies and donor organizations have collaborated to whitewash Bhutan's royal government, to accept without guffaws the king's pap about "Gross National Happiness" even while he perpetrates one of the more conspicuous programs of ethnic cleansing. Mountain Forum, which has the responsibility to facilitate exchange of information of practical importance to researchers and planners, has a policy of suppressing politically sensitive postings, thereby increasing the likelihood of a cultural "meltdown" with regional consequences outweighing those of natural hazards.

\section{Mountain hazard \#3: Global warming}

Global climate change has been linked to a cascade of potential or actual disasters at the regional or watershed scale. These include increased incidence of avalanche, proliferation of GLOFs, and disappearance of glaciers, resulting in loss of tourist attractions as well as disruption of the water supply on which local and downstream ecosystems depend.

These days very few scientists deny that unusually rapid climate change is occurring and that human activity is a significant factor. Jack Ives does however take issue with the tenor of discourse on this significant issue. Ives equates the Cassandraism that pervades discussion of global warming with the previous exaggerations of the danger of deforestation. He cites predictions by the World Bank and the Asian Development Bank that "no accessible forest would remain in Nepal by the year 2000" and compares these with such reports as the 2002 article by Fred Pearce in the New Scientist in which John Reynolds is quoted as warning that "the 21st century could see hundreds of millions dead and tens of billions of dollars in damage [from GLOFs]." Reynolds has characterized this quote as "journalistic licence" and "an exaggeration" of his actual statement, although the potential impact of GLOFs and their secondary effects would affect significant numbers of people and have serious consequences for many vulnerable infrastructural installations and communities downstream. Regarding the prediction that the Himalayan glaciers will disappear and the Ganges shrink to a mere trickle, Ives wonders at the logic: even if the snow and ice gave way to rain, surely the rivers would still keep running!

The problem Ives alludes to goes beyond hysterical conclusions on the part of untrained reporters. He refers to misleading use of supposedly "replicate photographs" that purportedly illustrate glacial shrinkage. Reynolds argues that the shrinkage is real and probably under-reported, due to the fact that substantial thinning of a glacier can occur without much measurable decrease in surface area. 


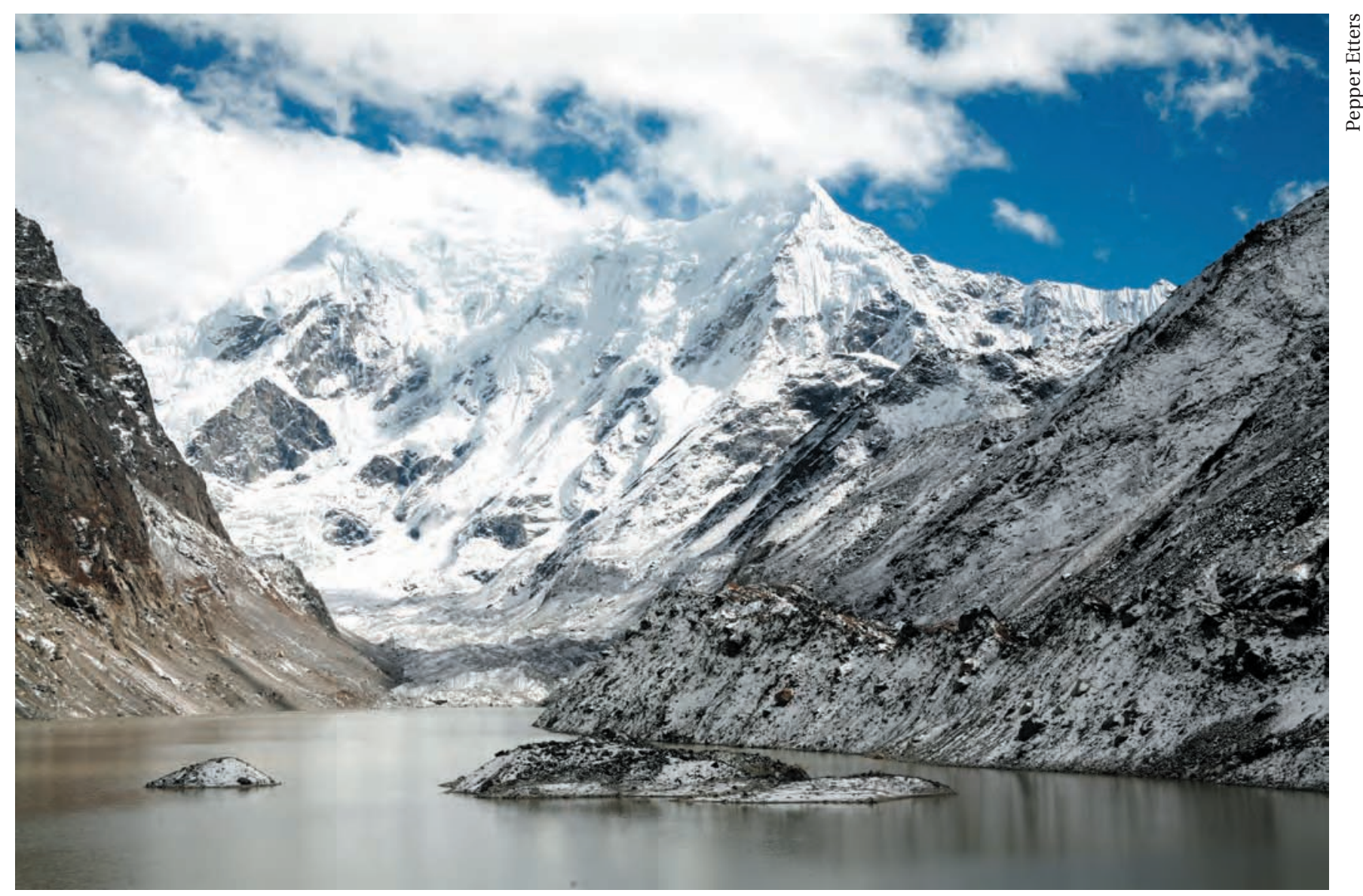

Band-Aid solution for a major GLOF threat: in 2000, an engineering project lowered the level of Tsho Rolpa (Rolwaling, Nepal) by 3.5 meters - less than one-third of the minimum recommended by experts.

As in Himalayan Dilemma, Ives is concerned with not only scientific credibility, the loss of which endangers us all, but also hazard inflation. When "supercrises" (with only long-term and speculative solutions) jostle for public attention, how can we make any headway on the more modest crises that can be addressed and remedied in the short term? He cites Alton Byers' work on the destruction of alpine vegetation as one of many unspectacular problems - and a somewhat unusual one in that Byers seems poised to address it effectively, thanks to a remarkable collaboration with the American Alpine Club.

On the specific issue of GLOF hazards, Ives notes that, contrary to prevailing wisdom, climate warming can be an attenuating factor. He explains that water accumulations next to and underneath glaciers normally become smaller and drains more frequently as the glacier shrinks. As for water accumulations behind moraines, they generally result in only one GLOF, since the breached moraine is no longer capable of impounding large quantities of water.

On this point, Reynolds concurs that "a warming trend will reduce the hazard pertaining to ice-dammed lakes while increasing that resulting from moraine-dammed lakes." However, Reynolds cautions that repeat GLOF events are possible, and gives the examples of Dig Tsho in Nepal's Khumbu (still a threat), and Artesanraju at Laguna Paròn
(Peru), which in 1951 experienced two GLOF events a few months apart.

\section{Mountain Hazard \#4: GLOFs}

Remote mountain tourism destinations are inherently at risk due to their relative inaccessibility, dynamic geology, and dramatic meteorology. The declivity and human settlement patterns (as well as recreational activities) particularly aggravate the risks of avalanche, landslide, and flooding. GLOFs have drawn attention in recent decades due to three factors:

- Like an inland tsunami, a GLOF can inflict a huge amount of damage over a great distance, and poses a devastating threat to vital infrastructure including hydroelectric plants, bridges, and roads and trails, as well as to entire communities.

- Like the legendary sword of Damocles, GLOF threats are relatively easy to identify; on the other hand, the timing of a given event is difficult to predict. And this sword cuts both ways: inaccurate prognostications may lead to panic and economic disaster.

- GLOFs are linked to climate change. They are likely to occur with greater frequency as glaciers retreat. It has been argued that they are also likely to become increasingly common currency in political discourse, not to mention posturing and hand-wringing. 


\section{GLOFs and Politics}

In his keynote presentation, "Fools rush in," Jack Ives notes that a United Nations University study of hazards in Kakani and Khumbu (Nepal) concluded that GLOFs represent the most serious mountain hazard in those areas, a conclusion underscored soon afterward by the outbreak of Dig Tsho, near Thame.

Political contingencies have hampered GLOF research and mitigation efforts. Essential aerial photography was classified as secret. Ives' recommendation that ICIMOD take a lead in studying and mapping the hazards was ignored by ICIMOD under Dr Rosser. Although DrVic Galay and individual staff members of the Water and Energy Commission provided assistance for Ives' research, His Majesty's Government (HMG) ignored their recommendations. Only after global warming had become a sexy topic in the mid-1990s did ICIMOD (with UNEP support) produce an inventory of potentially hazardous glacial lakes in Nepal and Bhutan.

\section{Arun III Hydro-Electric Power Project}

Jack Ives gives a semi-insider's account of the politicization of GLOF hazards as pertains to the aborted Arun III hydropower project. According to Ives it was due to the generalized GLOF fears that the World Bank and HMG undertook a narrowly focused review of the project in 1995. Only GLOF threats in the Arun Valley itself were to be discussed, and all other factors were excluded from the review. While there was no evidence of a GLOF hazard to the hydropower site itself, Teiji Watanabe passed on to Ives his findings about the serious GLOF threat posed by Imja Lake in the neighboring valley.

\section{Volunteer expedition brings modern health care to Rolwaling}

I $\mathrm{n}$ the fall of 2000, I spent a month in Rolwaling as a member of Bridges-PRTD ("Projects in Rational Tourism Development"), a private volunteer/study abroad company that had was trying to help promote backpacker tourism as a resource for economic development. (See www.bridges-prtd.com.) We were quartered at the main village of Beding $(3700 \mathrm{~m})$, some thirty drab houses clustered around a small monastery about six days' trek up from the road head at Dolakha. At the time, there was no electricity, no health clinic, no functioning school. The monastery was dilapidated and the stupa had been washed away by a GLOF. Every able-bodied man and most of the women had left to work elsewhere as porters and guides, leaving only a few dozen women, children, and lamas to tend the fields.

Although our resources were limited, we did set up a handful of teahouses - merely by providing signs and English menus; we bought some paint and lumber and gave the gompa a face-lift; we identified and marked a suitable waste disposal site; we gave a few lectures on first aid, and donated a trunk-load of medical supplies. A Kathmandu engineering firm was hired to produce a feasibility study and design for a micro-hydro plant.

Since 2003, Bridges-PRTD had suspended operations due to the political instability in Nepal. As often happens with small development efforts, we had raised hopes but failed to follow through with the kind of assistance that might make a long-term difference.

Last October I was finally able to pull together an expedition of health care professionals with the objective of decisively upgrading healthcare facilities in Beding and sharing with this remote community the advantages of modern science. The team included my wife Jody Swoboda Etters, Medical Director Laurie Strasburger PA-C, Ken Zawaki MD, Ami Zawaki MD, Kristi LaRock PA-C, Clairane Vost RN, Tom Willard EMT, Vannessa
Willard, Eddie Sandoval and Perry LaRock. Our support network included anthropologist Janice Sacherer, climber Nick Arding, Everest veterans Jon Gangdal and Dawa Chirri Sherpa of the Rolwaling Foundation, and Scott MacLennan and his staff at the Mountain Fund. Unlike the situation that prevailed back in 2000, when virtually no one outside Nepal had heard of Rolwaling, there is now an international web of individuals and groups interested in both the valley and its people.

On the trail north along the Tamba, not much had changed since 2000. The road had been extended to Singate, which meant we didn't have to deal with the 2000m descent (and ascent, coming back) just northeast of Dolakha. There were no signs of the sort of prosperity you see along the Everest trail - the fact that Rolwaling had been closed to independent trekkers for thirty years meant that most visitors passed through in self-contained caravans, contributing precious little to the economy. The Maoist insurgency effectively removed the official restrictions on travel, but few tourists wanted to face being shaken down for a "contribution."

At our first stop, we happened on a man carrying his eleven-year-old daughter in a dhoko, a conical wicker basket supported by a tumpline over his head. They were coming from Simigaon, racing toward the hospital in Dolakha, although they had no money and were not optimistic about getting help. It turned out that the girl had a serious kidney infection which had lead to sepsis. For two days we treated her with intravenous fluids and antibiotics. It was touch-and-go the first night, but when we parted ways she was walking and on her way to recovery. We were soon besieged by requests for medical assistance.

In Beding, there were signs of activity. A new stupa had been constructed, a new school built and staffed, and a diversion project had been along the river - not 
Ives was able to argue that if Imja gave way, the catastrophe would cause such consternation that it would likely derail the nearby Arun III project. According to Ives, this argument proved trenchant; in the end, it was fear of bad publicity, rather than concern for human safety and ecological sustainability, that led the German and Japanese to withdraw their support, and killed the project.

John Reynolds provides a somewhat more nuanced but not necessarily contradictory account of the demise of Arun III. According to Reynolds, the main consultants to the project had given the go-ahead on the basis of outdated maps which showed no glacial lakes in the area. Alert members of the Water and Energy Commission Secretariat (WECS) staff showed Reynolds much more recent photographs that revealed there were indeed glacial lakes in the Arun

to mitigate a potential lake outburst, but to control the normal monsoon floods. The Rolwaling Foundation is moving ahead with plans for a small hydropower plant to supply households with electricity as well as to develop local lodges so that independent backpacker tourism can finally take off.

After settling into the host families' homes, the team was welcomed to the village with a tea ceremony in which all the community members offered katas (ceremonial scarves) and blessings to the volunteers. Following the ceremony, we set to work. There was a side room attached to the school, and we converted that into a clinic, installing furniture and medical supplies. Solar panels provide light and charging capacity for small equipment, including a microscope donated by Colorado Mountain Medical, a clinic in Vail, Colorado. At the same time, we undertook public health improvements in areas such as sanitation, drinking water, waste management, nutrition and first aid training.

Meanwhile we were training Jangmu, the Nepali nurse hired to run the clinic on a long-term basis. Together we treated villagers for a variety of complaints. There were relatively few acute infections and injuries, while chronic and persistent disorders were much more prevalent. Respiratory diseases, cataracts, arthritis, tooth decay, gingivitis, and arthritis are all too common. While we were able to deal with most problems, several could not be addressed without more advanced diagnostics. A few members of the community may have cancer and other life threatening illnesses, but without making the trek to Katmandu, we couldn't be sure, much less provide effective treatment.

During the ten days we spent in the Rolwaling Valley, we also encountered a substantial demand for medical services on the part of tourists. Despite the fact that most packaged tours had medical supplies and trained staff, we were called on to provide assistance for quite a few cases of altitude sickness. As tourist traffic increases, we expect this need to increase.

We have begun to look for resources to address catchment. At the request of the World Bank, Reynolds produced a "notional scheme" to assess the actual hazard and was granted $\$ 500,000$ to carry it out, but the entire scheme was suddenly aborted; to date, no glacial hazard assessment has ever been carried out in the Arun Valley. Reynolds reports that the Germans withdrew because they

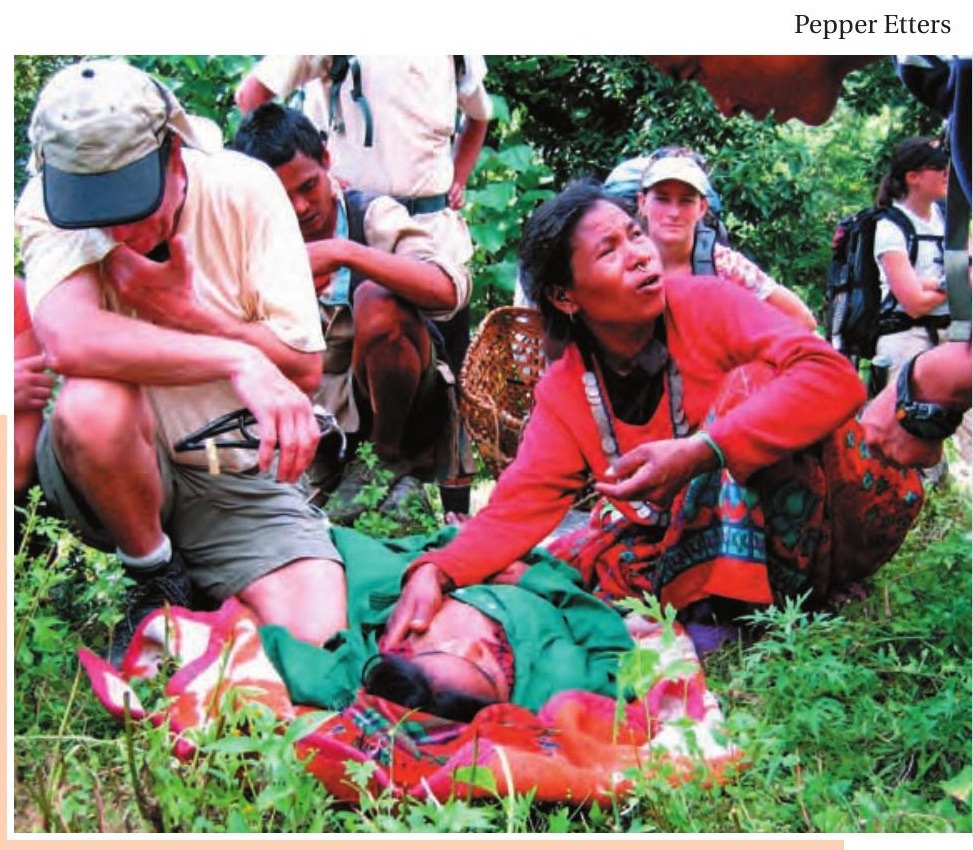

these issues and hope to bring volunteer specialists including dentists and oral surgeons, eye surgeons and orthopedists as well as additional general practitioners who will continue to train and support Jangmu and her eventual successors so that they can continue to care for the community with whom they have been entrusted.

On a personal note, I would like to add that I am saddened by the recent death of Sir Edmund Hillary. Both as a member of Bridges-PRTD and as the organizer of this medical expedition, I have been keenly aware that we are following in the huge footsteps of the man who gave the world an enduring model of volunteer development. Sir Edmund undertook only those projects specifically requested. He made it clear that he was undertaking this work out of gratitude for Sherpa collaboration on a project that had brought him immense personal satisfaction (as well as world fame). He didn't proselytize or set conditions; he came and personally participated in the projects; and he returned, again and again and again. I hope that the death of Sir Edmund will remind people of his work, and the work that remains to be done. The need is great, and the experience is life-transforming.

\section{Pepper Etters}

Pepper Etters directs Rolwaling Health Care Project, and owns Adventurous Spirit Photography (http:// www.adventurousspiritphoto.com/splash.php). 
considered the project "flawed," but not because of the Imja Lake GLOF hazard. Based on research subsequently carried out by his team, Reynolds does not consider Imja Lake a "major hazard," although he says it should be monitored.

\section{Rolwaling}

According to John Reynolds' account, concern about the GLOF risk at Tsho Rolpa can be dated to the 1991 outbreak flood from Chubung, a much smaller lake; the damage from this relatively minor event led the community to start worrying what would happen if the much larger Tsho Rolpa were to give way.

Even after the partial fix, the known threat from Tsho Rolpa is much greater than that from any other Himalayan glacial lake. According to the Web site of the Department of Hydrology and Meteorology,

If the dam breaches, about 30-35 million $\mathrm{m}^{3}$ of water could be released and the resulting GLOF could cause serious damage for $100 \mathrm{~km}$ or more downstream, threatening lives, villages, farmland, bridges, trials, roads, 60 MW Khimti Hydro power and other infrastructure.

The story of the Tsho Rolpa mitigation project is in many ways just as alarming as the hazard threat itself. Even Reynolds' brief account is far too detailed to bear summarizing here, but I will highlight some of the points that I consider most telling.

1. Pleas for assistance from the Sherpas themselves were ignored both by the Nepalese government and by the many embassies they addressed. It was only the fortuitous visit and subsequent persistence of a Dutch national that resulted in international assistance. This unforeseeable good fortune was frittered away in a diplomatic freezeout between the Netherlands and Nepal that developed out of an incident involving an unauthorized Dutch movie filmed in Nepal. Although Reynolds himself does not explicitly make the point, I think it is rather clear that without his largely pro bono work, and his unusual prior experience in Peru, the Tsho Rolpa project would not have had much chance of success. In other words, there simply was no viable procedure in place capable of dealing routinely with such hazards; that situation persists today largely unchanged.

2. Efforts to mitigate the Tsho Rolpa threat were stymied by political insouciance and bureaucratic malice. In 1996, after several years of research and experimentation with siphons, the project was moved from the Water and Energy Commission Secretariat (WECS) to the Department of Hydrology and Meteorology (DHM). The WECS GLOF unit was cut loose. The Japanese workers went home. Some Nepalis went to ICIMOD. Reynolds observes, "This has been the source of the friction between ICIMOD and DHM ever since and was to play a part in the public fracas associated with the 1997 work."

3. Plans developed by scientists in consideration of extremely important circumstances were unwisely disregarded by bureaucrats both in Nepal and elsewhere. The Dutch eliminated Reynolds' proposal for “integrated hazard management," resulting in a situation where the locals do not have resources or expertise to manage the project after installation.

4. The 1997 panic over an impending outbreak flood at Tsho Rolpa was due to irresponsible and inaccurate reporting by the media, aggravated by what Reynolds characterizes as "sniping from the sidelines by former WECS staff who were opposed to DHM's handling of the matter and were holding press conferences that had the effect of undermining DHM's position."

5. While the Tsho Rolpa GLOF Risk Reduction Program successfully reduced the lake level by 3.5 meters in 2000, research conducted between 1997 and 2000 led scientists to conclude that internationally recognized safety standards could be achieved only through further reduction by 11.5 meters, and preferably by 16.5 meters. This recommendation, along with recommendations that the moraine be monitored on a continuing basis, has not been implemented. In fact, moraine stability has not been assessed since 2000. Given Reynolds' findings that thermokarstic degeneration within the moraine can occur more rapidly than previously suspected, further remediation efforts are urgently needed.

\section{Tsho Rolpa: the human impact}

According to oral histories collected by Janice Sacherer, the only notable event reported up to the time of her doctoral research in 1974 was the temporary blocking of the Rolwaling River by a snow avalanche; this occurred sometime between 1900 and 1950 and there were no fatalities.

A warming trend is responsible for more recent developments. The thawed moraine on the north side of Tsho Rolpa has turned the trail over Tashi Labtsa pass $(19,000 \mathrm{ft}$ above sea level) into a monstrous Plinko game, with rocks of all sizes careening down on travelers. In the late 1990s, traffic shifted to a new longer trail on the south side of the glacier.

There have also been two GLOFs in recent decades. In 1979, a comparatively small event issued from a southfacing glacier on Menlung Pass directly north of Beding, and resulted in the death of a woman who was grinding grain at a water-powered mill at the confluence of the Menlung stream and the Rolwaling River.

Regarding the second GLOF, I quote Sacherer's account:

In 1991, a much larger GLOF occurred when a lake under the ice of the Ripimo Shar glacier, a south facing glacier on the east side of a small high altitude northsouth valley above the village of $\mathrm{Na}$, burst through the ice. This happened in the late afternoon of a summer religious festival ... in the village of Beding when almost all of the Rolwaling people were gathered at the temple in Beding. The villagers first noticed that the Rolwaling River had turned brown and then that it began rising rapidly. Dressed in their holiday finery, they ran uphill, as Beding is located in a narrower part of the valley. The flooding went on until dark, washing away the village chörten and some houses and potato fields. Thus the people of Rolwaling spent the entire night out in the open in the rain, as high on the hill as they could climb. 
Today, they are still dealing with the erosion caused by the river and the loss of some of their best potato fields.

Sacherer disputes the accuracy of certain press reports on the reaction of the Rolwalingpa to the Tsho Rolpa threat. Contrary to assertions that the Sherpas were not disturbed by the threat because they consider Tsho Rolpa the sacred precinct of a goddess, she points out that while nearby Oma'i Tsho (fed by Ripimo Shar glacier) is sacred to the local goddess Tseringma, Tsho Rolpa is said to be the home of only a few lü (naga), lower-status snake divinities. If there was a perception that the Rolwaling people were not afraid, Sacherer suggests that it was probably due to "Sherpa fatalism and courage in the face of adversity" rather than lack of concern.

According to Sacherer, fear of an outburst of Tsho Rolpa was a major factor leading to outmigration of most of the Rolwaling community. About $85 \%$ of the population now spend nine or more months outside the valley. She admits that Kathmandu offers advantages other than safety, including comfort, as well as better employment opportunities and schooling for the children; moreover, for newly wealthy mountain guides and tour operators, building a house in Kathmandu is a better investment than building one in Rolwaling given that both government policies and the Maoist insurgency had effectively impeded tourism.

The result, according to Sacherer, is that the permanent residents of Rolwaling are "predominantly the old, the poor, the alcoholic, the incapacitated, and those with no close relatives in Kathmandu - the very people who could least afford to lose everything." Furthermore, since the likelihood is that a GLOF would strike during the monsoon, when most of the economically productive members of the community are in the valley, the disaster would have long-term repercussions. Since the valley has little usable space, most of which would be rendered useless by debris, the valley would probably be abandoned, which Sacherer speculates would have a "national impact, as an abandoned valley lying just south of the Tibeto-Chinese border would not be seen as politically desirable from the Nepalese government's point of view."

Based on interviews conducted during three BridgesPRTD expeditions to Rolwaling, I doubt that the GLOF threat is the immediate cause of current out-migration from Rolwaling. As Sacherer points out, most of the community returns to the valley precisely when it is most vulnerable - and when comfort and employment opportunities in Kathmandu are at low ebb. Furthermore, many Rolwaling informants seem dubious of the imminence of the threat. This may be due to the fact that the widely publicized predictions of 1997 did not come true, and also because people have been reassured by the 3-meter reduction in the lake level. (A recent communication from Sacherer notes that "As for Tsho Rolpa, [the Rolwalingpas] unanimously trust in western technology and believe that there is no further danger because of the amelioration work already done.")

Whether or not the GLOF risk is still a factor in outmigration, Sacherer is clearly correct that the hazard has hampered attempts to raise funds for development in Rolwaling. Without electrification (and light, heat, telephones, and internet), the Kathmandu-educated

\section{Urgent recommendations from "Mountain Hazards, Mountain Tourism" symposium include: \\ - rigorous application of available assessment and mitigation technology, \\ - international attention to simmering Bhutanese problem, and \\ - conversion of King Gyanendra's palace into a Disaster Management University.}

generation will probably not return to settle in Rolwaling. Certainly, there has been a delay in the development of teahouse tourism, and concomitant economic opportunity, due to the lack of amenities.

\section{Perceived development needs in Rolwaling}

Based on interviews in Kathmandu and correspondence with recent visitors to Rolwaling, Sacherer reports on the status of development. These are the areas of need most commonly cited:

River containment Sacherer reports that the most pressing need is for control of the Rolwaling River, especially as it passes Beding. In the 1990s, the river destroyed the largest area of arable land in the area, in addition to the village chörten and three houses. The greatest damage was caused by the 1991 Chubung GLOF. However, the containment walls that were undertaken in 1999 were intended primarily to manage the high waters from annual monsoons. Based on my observations and reports from village members, the initial lowering of Tsho Rolpa was well managed and caused no damage.

According to recent information from Dr Sacherer, a more ambitious river control project has been already begun with the aid of Dr Ruedi Baumgartner and Swiss Development Cooperation. Again, it seems unlikely that this project could be intended to control an outbreak flood from Tsho Rolpa.

Gompa restoration Now that the ruined gompa at Na (an hour above Beding) has been rebuilt, the monastery at Beding is an important priority. The Beding gompa is the spiritual center of Rolwaling, a beyul or "sacred valley" according to Tibetan Buddhist tradition. It is also the center of community social life, hosting a year-round series of village festivals. In 2002, Bridges-PRTD volunteers donated materials and labor to complete the precinct gateways and repaint the outer walls and metal ornaments. However, the outer frescoes are damaged, and those inside are in danger. Sacherer reports that she has donated money and mobilized resources to undertake a more substantial rehabilitation of the Beding gompa.

Health clinic There is a strong consensus on the need for a health clinic, or, if that proves impossible, a mobile team, training for a village health worker and further supplies 
of the type Bridges-PRTD donated several years before, which informants agree was well administered by Ngawang Chokling. Currently, Pepper Etters, a former Bridges-PRTD associate, is organizing a medical expedition which will bring supplies and training in the fall of 2007 (see box on p 14).

School The school at Beding was originally built by Sir Edmund Hillary. However, it was unused in recent years, both because of delapidation and because the schoolteachers prove unreliable. Several years ago John Reynolds gave a considerable sum to be used for educational upgrades, but the entire amount was reportedly embezzled and spent on chang (local beer). More recent efforts have resulted in a larger and better heated structure, but staffing remains a problem.

Electricity In 2001, Bridges-PRTD commissioned a Kathmandu-based engineering firm to do a feasibility study for a $3.5 \mathrm{kw}$ Peltric set that would have provided electric lighting in all permanent households as well as the school and gompa. Half the cost would have been underwritten by a Nepal government program, leaving only about $\$ 5,000$ to raise. However, given the activities of the Maoist insurgents, it was impossible to proceed with this effort. More recently there have been renewed explorations of electrification schemes.

For the most part, the people of Rolwaling maintain a cohesive community near Bouddha, just east of Kathmandu proper. They would like to see enough modernization and economic prosperity to interest their children in returning, or at least to make it place for comfortable summer and retirement. They are willing to invest their own resources, and, like the Khumbu Sherpas, they have international friends with deep pockets. If the GLOF threat is lifted and if the new democratic government of Nepal does not reinstate the restrictive measures that prevented development of teahouse trekking, Rolwaling has a good chance of reinventing itself before an irreversible diaspora sets in. But there isn't much time.

\section{Moving ahead}

An essential element of any disaster management program must be the perception of scientific objectivity. Whatever the reality behind the debacles discussed in our e-conference, we know for sure from the sordid tale of Hurricane Katrina that political cronyism, incompetence, profiteering, racism, and indifference can and do compete with heroism, altruism and sound judgment. What can be done to mitigate the likelihood of bad disaster management?

Again, the media have an important role to play in disseminating information; we should not and they cannot be expected to be reliable unless there is an authoritative entity to serve as an information clearinghouse. Who will take on that role?

Finally, we need to establish a firewall between engineering consultants who assess risk and those who design infrastructure, in order to eliminate the potential for and perception of conflict of interest. With the limited available expertise pertaining to complicated hazards and development projects, is it reasonable to hope for enough redundancy to keep these roles separate?

\section{Disaster U}

Perhaps the time is right to found a new type of academic institution: one based on a real-world problem rather than a preconceived "discipline." Why not establish a Disaster Management University? Here are some of the considerations:

1. Many types of disasters are unlikely or rare enough that it doesn't make sense to design an academic career specifically for them. These would include asteroid collision, nuclear terrorism, bird flu, mid-plate volcanism and earthquake, and others. Even though they may seem to pertain to disparate fields, they have important strategic points in common, particularly rescue and evacuation.

2. The existence of a recognized degree would make it less likely that incompetents would get into positions where they can make the disaster more catastrophic (such as the directorship of FEMA).

3. The establishment of a single Disaster U, presumably at the graduate level, would probably inspire universities around the world to offer disaster management as an undergraduate degree. This would assure enough redundancy of expertise to allow for informed debate, peer review, and separation of interests.

Kathmandu would be a logical location for an international university of this sort because of the concatenation of man-made and natural hazards. Specifically, the royal palace would present a perfect campus. (Presumably the King would be offered a less pretentious and portentous domicile somewhere outside the capital, as befits a modern constitutional monarch.) Apart from the substantive contributions to local as well as regional safety, an international university would be a significant foreignexchange magnet for Kathmandu.

\section{A protocol for glacial hazard assessment}

Subsequent to the Arun-III debacle, the World Bank modified its policy, requiring that proper glacial hazard assessments be undertaken prior to approval of hydropower projects. The UN followed suit. Yet there was no definition of what that assessment should entail. Furthermore, the terminology varied; one Peruvian project required a glacial hazard analysis, without further specification. Interpretation was left up to contractors bidding on the project, and in the end the successful bidder came up with a minimalist version.

On the other hand, there is the danger that perceived - rather than demonstrable - hazards will be taken as sufficient to block a hydropower project. Given the economic importance of these projects, such a perspective could have a devastating effect on Nepal and other countries where hydropower is the principal natural resource.

The alternative to emotive and subjective characterizations is a scientific protocol with clearly defined criteria for the assessment of risk at any given site. Reynolds summarizes the tools currently available:

...It is now possible to identify and map glacial lakes using remote sensing techniques and to produce Digital Elevation Models from stereo satellite images; to derive an inventory of glaciers and map all glacial lakes using 
both manual and semi-automatic land classification procedures; to monitor flow rates as small as $2 \mathrm{~cm} /$ day for debris-covered glaciers using Synthetic Aperture Radar imagery; and to map where proto-supra-glacial lakes are most likely to develop in the next two to three decades. Working with colleagues originally at the University of Zurich it is possible to calculate and map the probability of inundation from debris flows and glacial lake outburst floods. Since 1996 we have also developed and tested different geophysical techniques on moraines to determine if they are ice-cored or not at a wide variety of Himalayan glacial lakes (e.g., Delisle et al. 2003, Hanisch et al. 1998, Pant and Reynolds 2000, Reynolds 2006).

In 2000, the [British] Department for International Development awarded Reynolds Geo-Sciences Ltd (RGSL) a 3-year contract "to develop glacial hazard and risk minimisation protocols in rural environments." The result is a set of weighted criteria that can be measured by nonexperts and plugged into formulas that yield an objective glacial hazard rating. Details are available online either through RGSL's web-site (www.geologyuk.com) or through the British Geological Survey's web-site (www.bgs.ac.uk; DFID Knowledge and Research portal, then Search for Glacial hazards). The system has since been adopted by the Union Commission for the Cryospheric Sciences Working Group on Glacial and Permafrost Hazards.

Now that there are standards for risk measurement, it would make sense to have an international entity in charge of a well-publicized program. Such a Mountain Hazard and Disaster Watch could direct graduate students and other researchers to areas in need of study. It could serve as a clearinghouse to review, assemble, and track research, and as an authoritative source of prognostications and advisories.

\section{Localized efforts}

The Sherpas of Nepal have been very successful at developing ongoing "sponsorship" relationships with trekking and mountaineering clients. While comparable enterprise is not often found in other remote travel destinations, the likelihood is that it would be easy to develop. All that is required is that an organization gather email addresses of visitors to each locale, perhaps in exchange for news and photo updates. The email list could then be used to solicit donations in the event of catastrophe, as well as for development, and also to stimulate interest in return visits.

One local target should be to establish depots of rescue tools, blankets, and communication devices. Placement of the depots would necessarily entail some thought to emergency access and evacuation.

\section{Rolwaling}

Quite a few important opportunities have already been missed. As noted above, Reynolds' integrated disaster management/social development plan was not implemented. A great engineering effort was mounted that resulted in a very small draw-down of the lake level. The full draw-down plan was abandoned, meaning the lake is still dangerous, and unmonitored. We have heard reports of possible continuation of the project, but nothing firm yet. Reynolds concludes:

There is a clear consensus that the future viability of Rolwaling communities is tied up with the reduction in hazard at Tsho Rolpa, and infrastructure development within the valley. This must be done sensitively with respect to both the physical and social environments, and should include the provision of electricity and other social benefits, as other contributors to the e-conference have also suggested.

... As Dr Sacherer states in her article, unless Tsho Rolpa is remediated, the further development of Rolwaling will not happen and this is likely to lead to the demise of the communities within the valley.

In Rolwaling we have been afforded the luxury of a longdrawn-out training period. Tsho Rolpa will not be the last GLOF hazard. Whatever we learn there will certainly have applications elsewhere. Let's hope the lessons are bestpractices, and not missed chances. 